\title{
Geochemistry of Marl Sediments within Fat'ha Formation at Selected Localities, Northern Iraq
}

\author{
Zeki A. Aljubouri \\ Department of Geology \\ College of Science \\ Mosul University
}

\author{
Hazim A. Al-Kawaz \\ Dams and Water Resources \\ Research Center \\ Mosul University
}

(Received 27/2/2008, Accepted 2/9/2008)

\begin{abstract}
A total number of (32) marl samples of Fat'ha Formation (Middle Miocene) was collected from four selected localities in northern Iraq. Geochemical study included the analysis of (13) major and minor oxides by x-ray fluorescence and wet chemical methods and (7) trace elements by (XRF). The study shows that the oxides $\left(\mathrm{SiO}_{2}, \mathrm{Al}_{2} \mathrm{O}_{3}, \mathrm{TiO}_{2}\right.$, $\mathrm{Fe}_{2} \mathrm{O}_{3}, \mathrm{FeO}$, most $\mathrm{MgO}, \mathrm{Na}_{2} \mathrm{O}, \mathrm{K}_{2} \mathrm{O}, \mathrm{MnO}, \mathrm{P}_{2} \mathrm{O}_{5}$ and $\mathrm{H}_{2} \mathrm{O}^{+}$) are in the detrital fraction which comprises around (58\%) of total mineral phases. These are clay minerals $(39 \%)$, quartz (15\%), iron oxides and Ti-minerals $(3 \%)$ and feldspar $(1 \%)$. The oxides $(\mathrm{CaO}$, some $\mathrm{MgO}$ and $\left.\mathrm{CO}_{2}\right)$ comprise the chemical fraction, the carbonates $(\sim 42 \%)$. The trace elements ( $\mathrm{Co}, \mathrm{Ni}, \mathrm{Ga}, \mathrm{Rb}, \mathrm{Zr}$ and some $\mathrm{Sr}$ ) are within the detrital fraction, mainly the clay minerals and iron oxides. The elements ( $\mathrm{Ba}$ and the remaining $\mathrm{Sr}$ ) are within the carbonate fraction. The oxides and elements of the detrital fraction, in general, have a negative correlation with oxides and elements of the chemical fraction. The red colour of marl sediments is primary caused by the red pigment of haematite. The green colour is secondary and resulted from the reducing environments, initiated by the presence of organic matter.
\end{abstract}

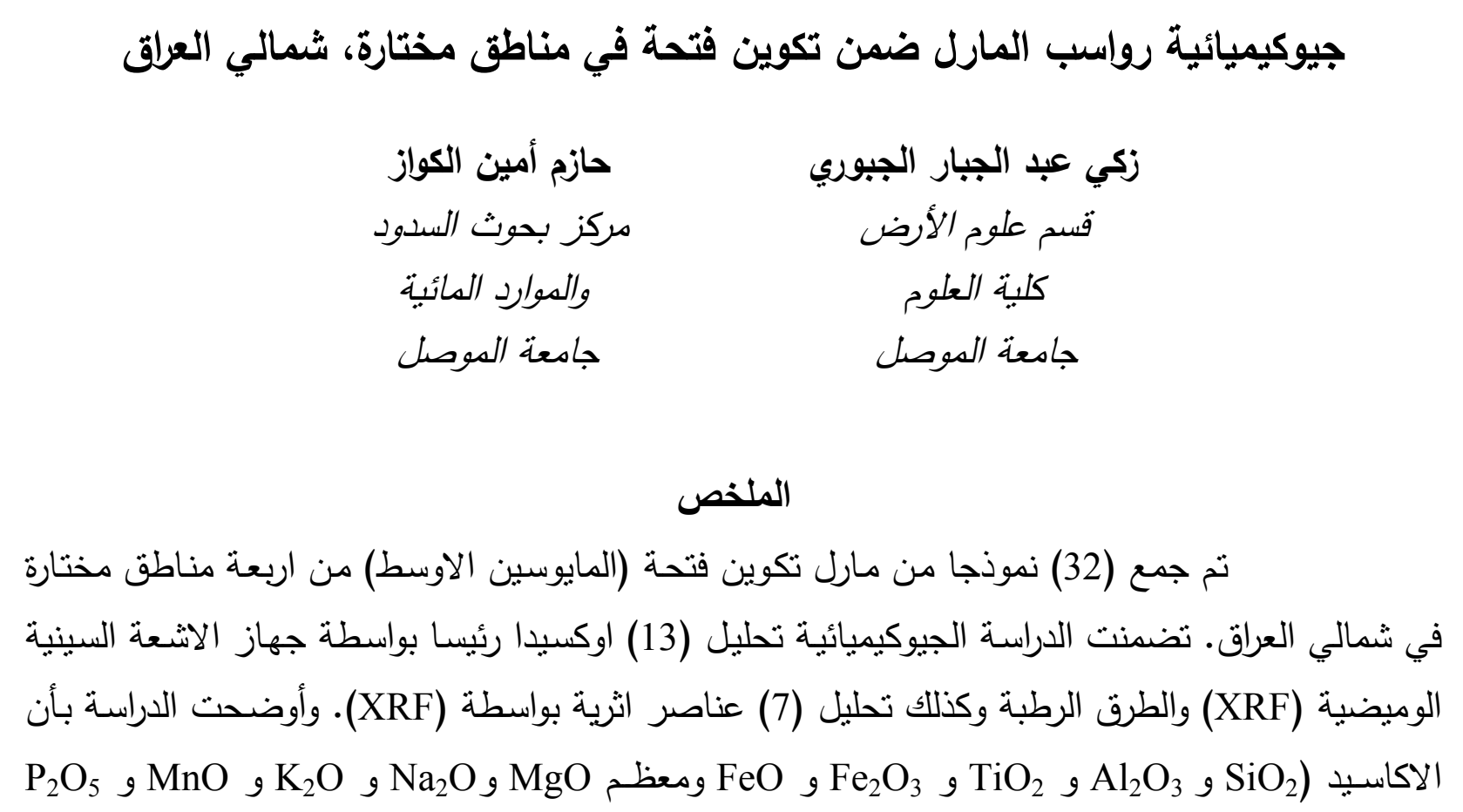


و هي ضمن الجزء الفتاتي الذي يشكل حوالي (58\%) من الاطوار المعدنية الكلية وهي: المعادن الطينيـة (39\%) والكـوارتز (15\%) وأكاسـيد الحديد مـع معـادن التيتـانيوم (3\%) والفلدسبار (1\%). وتمنثل الاكاسيد (CaO) بعض من MgO و

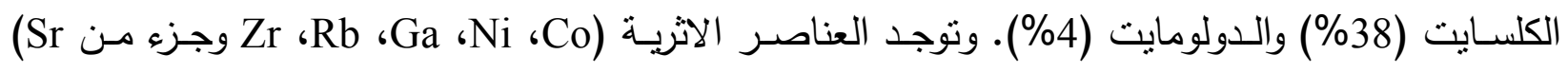
ضـمن الجزء الفتاتي أي ضــن المعـادن الطينيـة واكاسـيد الحديد). وامـا العنصـران (Ba والمتبقي مـن Sr) فيوجدان ضمن الجزء الكاربوناتي. وترتبط اكاسيد وعناصر الجزء الفتاتي وبصورة عامة ربطا سالبا مع اكاسيد وعناصـر الجزء الكيميائي. ان اللـون الاحمـر لترسبات المـارل اولي الاصـل ونـاتج عـن الصـبغة الحمـراء للهيمتايت. اما اللون الاخضر فهو ثانوي الاصل وناتج عن الظروف الاختزالية في منطقة المشراق، بوجود المواد العضوية.

\section{INTRODUCTION}

The area of study is situated at the northern part of Iraq within Nineva Governorate and includes four localities belonging to the Fat'ha Formation (Middle Miocene) (Fig, 1). Three of the localities (Shaikhan, Shaikh Ibrahim and Makhmur) are natural exposures, while the fourth (Mishraq) consists of borehole cores. The lithology consists of alternations, in cyclic fashion, of marls, carbonates and gypsum. A total number of (32) marl sample was collected from the four localities.

The purpose of this work is to study the geochemistry of marl sediments, through the distribution of and inter-element relationships between (13) major oxides and (7) minor and trace elements; to work out the normative mineralogy (mineral contents) from chemical analyses and to study the colour of marl sediments.

\section{ANALYTICAL TECHNIQUES}

Seven major oxides $\left(\mathrm{SiO}_{2}, \mathrm{Al}_{2} \mathrm{O}_{3}, \mathrm{Fe}_{2} \mathrm{O}_{3}\right.$ total, $\mathrm{CaO}, \mathrm{MgO}, \mathrm{Na}_{2} \mathrm{O}$ and $\left.\mathrm{K}_{2} \mathrm{O}\right)$ and seven trace elements (Co, Ni, Ga, $\mathrm{Rb}, \mathrm{Sr}, \mathrm{Zr}$ and $\mathrm{Ba}$ ) were analyzed by a Philips P.W. 1450/10 automatic X-ray fluorescence spectrometer. The pellet method (Norrish and Hutton, 1964; Leake et al., 1969) was used. The major oxides $\left(\mathrm{TiO}_{2}, \mathrm{MnO}\right.$ and $\left.\mathrm{P}_{2} \mathrm{O}_{5}\right)$ were analyzed by UV-VIS spectrophotometer, type Zeiss, PM6. Ferrous oxide (FeO) was analyzed by the macrovolumetric method of Wilson (1955). $\mathrm{CO}_{2}$ was determined by measuring the weight loss of the sample in $10 \% \mathrm{HCl}$ solution. $\mathrm{H}_{2} \mathrm{O}^{+}$was determined by total ignition loss at $1100{ }^{\circ} \mathrm{C}$ after subtracting the weight loss due to $\mathrm{CO}_{2}$. All analyses were carried out at the Department of Geology, College of Science, University of Mosul, Iraq.

The details of analytical techniques and the analyses of all (32) samples for major oxides and trace elements are given in Al-Kawaz (1980). 
Normative calculations are used in the present study to calculate the percentage of minerals, already found by X-ray diffraction. The method used depends on both X-ray diffraction and chemical analysis.

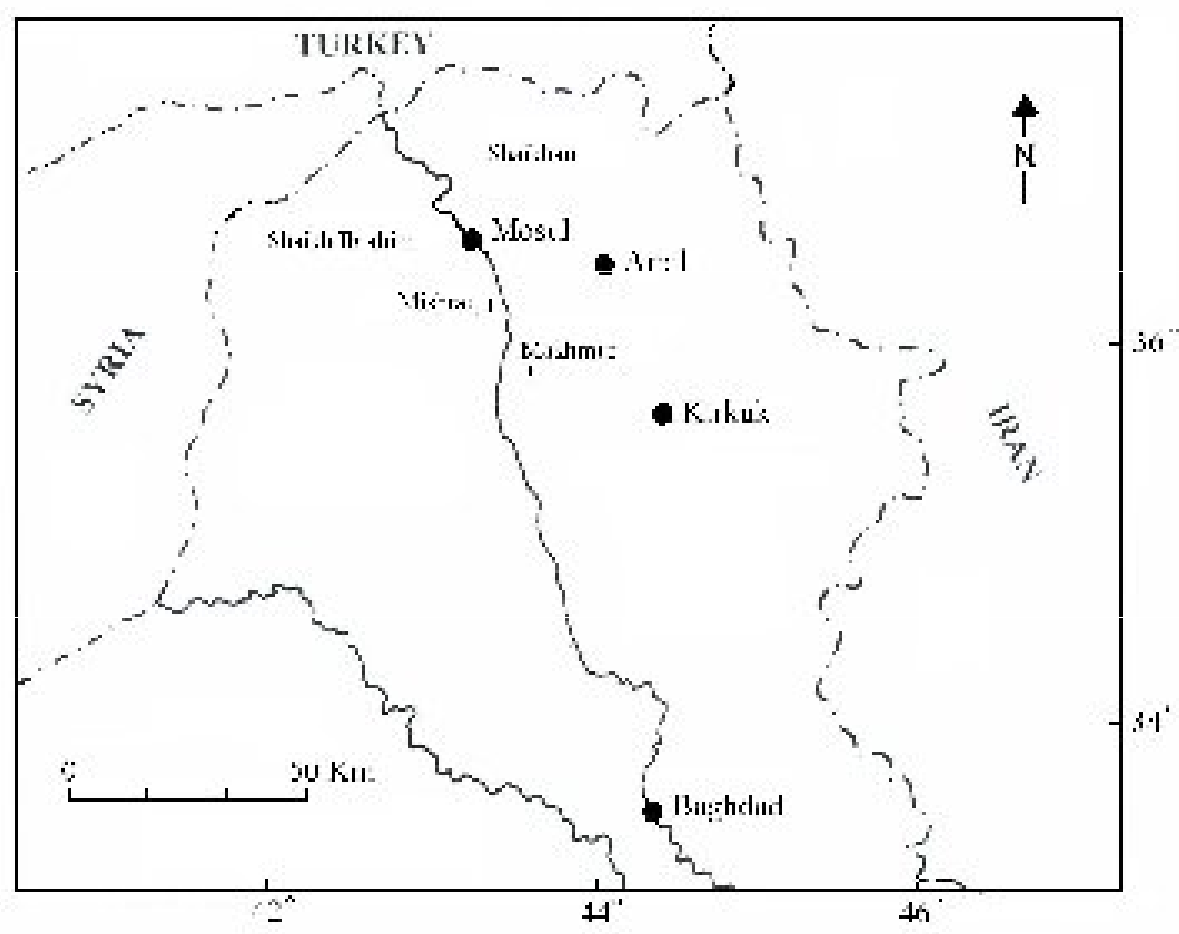

Fig. 1: The studied localities (+).

Using area under curve (Brindley and Brown, 1980) of the X-ray diffractogram of (Fig.2), (Al-Kawaz, 1980; Aljubouri and Al-Kawaz, 2006), the relative proportions of clay minerals and albite are illite $(71.64 \%)$, chlorite $(14.54 \%)$, kaolinite $(8.81 \%)$, montmorillonite $(2.20 \%)$ and albite $(2.64 \%)$. These proportions must be converted to real percentages of the marl of present study. This is achieved by using the average chemical analysis of marl in Table 1(A), and the ideal clay minerals and albite analyses in Table (2). $\mathrm{Al}_{2} \mathrm{O}_{3}$ is only restricted to clay minerals and albite. The total $\mathrm{Al}_{2} \mathrm{O}_{3}$ in the marl is distributed within clay minerals and albite according to their relative proportions found from (XRD). Using Table (2), the concentration of $\mathrm{Al}_{2} \mathrm{O}_{3}$ in each mineral is then converted to mineral percentage in the marl (Table 3).

The next step is to calculate the non-clay minerls. Quartz is calculated after subtracting all $\mathrm{SiO}_{2}$ in the clay minerals and albite from total $\mathrm{SiO}_{2}$ (Table 1); then the remaining $\mathrm{SiO}_{2}$ is allocated to quartz. Haematite $\left(\mathrm{Fe}_{2} \mathrm{O}_{3}\right)$ and Ti-minerals are calculated after subtracting $\left(\mathrm{Fe}_{2} \mathrm{O}_{3}\right)$ and $\left(\mathrm{TiO}_{2}\right)$ in the clay minerals. The remainings are allocated to haematite and Ti-minerals (mainly rutile) respectively.

Carbonates (calcite and dolomite) are calculated from the following empirical equation for a mixture of the two minerals from zero to $(100 \%)$ :

Calcite\% $=315.989+97.918 \times\left(\mathrm{CO}_{2} / \mathrm{CaO}\right)^{2}-354.10 \times\left(\mathrm{CO}_{2} / \mathrm{CaO}\right)$. 


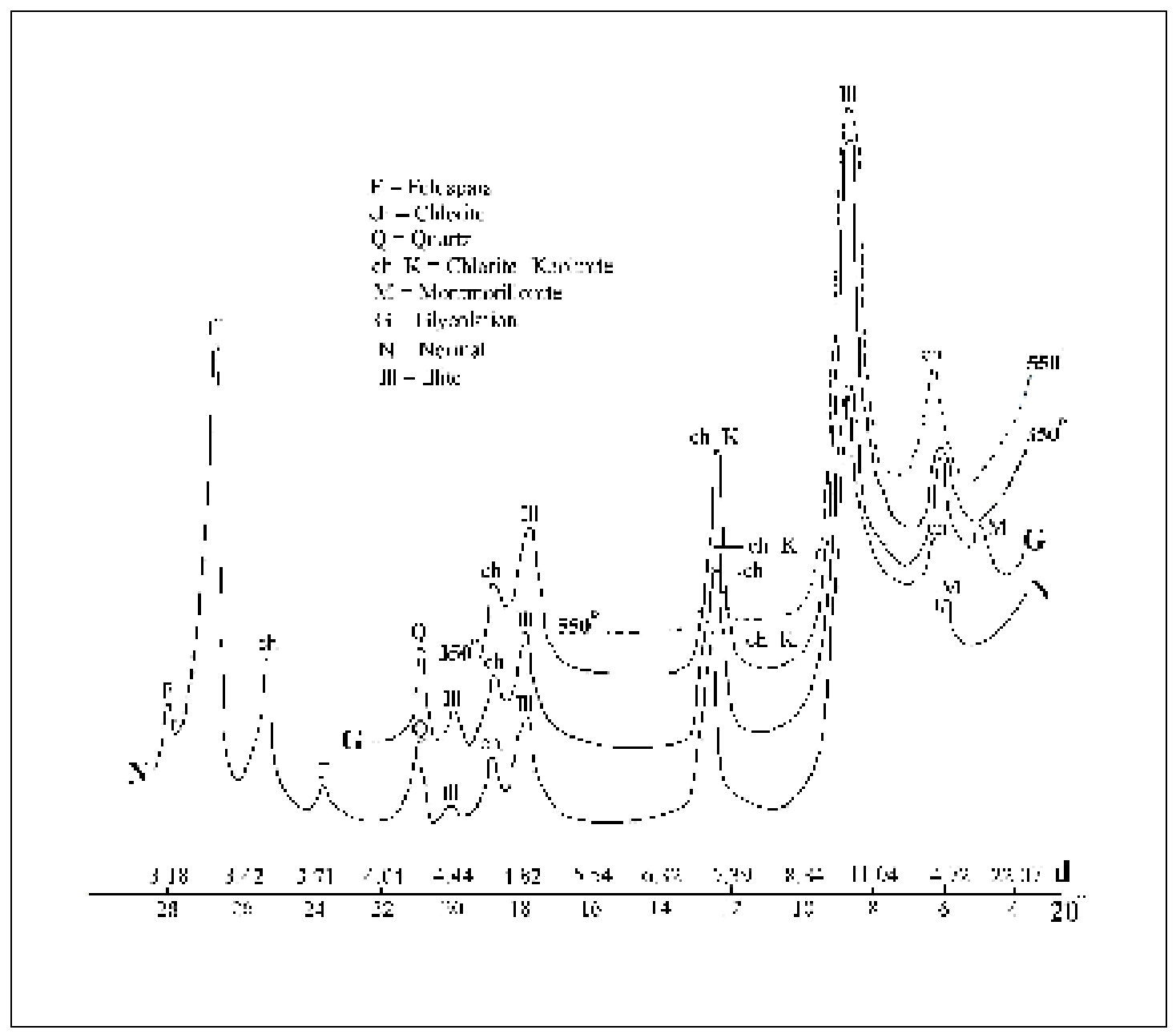

Fig.2: X-ray diffractograms for the clay minerals in the studied localities. From: Al-Kawaz, 1980; Aljubouri and Al-Kawaz, 2006).

The equation is deduced from the calculations of the ratio of $\left(\mathrm{CO}_{2} / \mathrm{CaO}\right)$ for each mix of calcite or dolomite and regressing the values against calcite percent (Fig. $r$ and Table 4). Figure ( $r$ ) shows the plot of this ratio versus calcite $\%$ or dolomite $\%$, so that either the equation or the figure could be used for calculating dolomite or calcite proportion, which is then converted to real percentage in the marl.

Alternatively, dolomite is calculated first after subtracting $(\mathrm{MgO})$ in the clay minerals from total $(\mathrm{MgO})$, and the remaining is allocated to dolomite. Calcite is then calculated after subtracting $\mathrm{CaO}$ in the clay minerals and in dolomite, then the remaining is converted to calcite. The value is chosen (for calcite or dolomite or both) which when added with other mineral phases values gives a total between (99 and 100). The normative mineral composition is given in Table (3). 
Table 1: Average analysis of marl of the present study (A) compared with average shale (B), normalized data (C) of (A), red marl (D), green marl (E) and drab marl (F) samples.

\begin{tabular}{|c|c|c|c|c|c|c|}
\hline Oxide \% & $\begin{array}{c}\text { (A) } \\
\text { Present } \\
\text { study } \\
\text { n=32 }\end{array}$ & $\begin{array}{c}\text { (B) } \\
\text { Average } \\
\text { shale }\end{array}$ & $\begin{array}{c}(\mathrm{C}) \\
\text { Present } \\
\text { study } \\
\text { *Normalized } \\
\mathbf{n}=32\end{array}$ & $\begin{array}{c}\text { D) } \\
\text { Red } \\
\text { marl } \\
n=12\end{array}$ & $\begin{array}{c}(\mathrm{E}) \\
\text { Green } \\
\text { marl } \\
\mathbf{n = 1 0}\end{array}$ & $\begin{array}{c}(\mathbf{F}) \\
\text { Drab } \\
\text { marl } \\
\mathbf{n}=\mathbf{1 0}\end{array}$ \\
\hline $\mathrm{SiO}_{2}$ & 33.77 & 58.83 & 58.41 & 33.98 & 37.68 & 29.60 \\
\hline $\mathrm{Al}_{2} \mathrm{O}_{3}$ & 8.30 & 16.63 & 14.36 & 8.25 & 9.45 & 7.23 \\
\hline $\mathrm{TiO}_{2}$ & 0.44 & 0.77 & 0.76 & 0.47 & 0.49 & 0.37 \\
\hline $\mathrm{Fe}_{2} \mathrm{O}_{3} \mathrm{t}^{* *}{ }_{\mathrm{t}}$ & 5.59 & 6.71 & 9.67 & 5.79 & 6.22 & 4.72 \\
\hline $\mathrm{Fe}_{2} \mathrm{O}_{3}$ & 4.22 & -- & -- & 5.13 & 3.49 & 3.86 \\
\hline $\mathrm{FeO}$ & 1.23 & -- & -- & 0.59 & 2.46 & 0.77 \\
\hline $\mathrm{MgO}$ & 5.37 & 2.49 & 2.49 & 4.05 & 7.20 & 5.13 \\
\hline $\mathrm{CaO}$ & 22.76 & 2.24 & 2.24 & 24.50 & 17.24 & 26.20 \\
\hline $\mathrm{Na}_{2} \mathrm{O}$ & 0.24 & 0.80 & 0.42 & 0.26 & 0.32 & 0.14 \\
\hline $\mathrm{K}_{2} \mathrm{O}$ & 1.33 & 3.21 & 2.30 & 1.22 & 1.51 & 1.29 \\
\hline $\mathrm{MnO}$ & 0.10 & 0.11 & 0.17 & 0.10 & 0.11 & 0.08 \\
\hline $\mathrm{P}_{2} \mathrm{O}_{5}$ & 0.18 & 0.16 & 0.31 & 0.19 & 0.18 & 0.17 \\
\hline $\mathrm{H}_{2} \mathrm{O}^{+}$ & 3.61 & $* * * 5.00$ & 6.24 & 3.94 & 3.48 & 3.38 \\
\hline $\mathrm{CO}_{2}$ & 17.78 & $* * * 2.63$ & 2.63 & 16.61 & 15.67 & 21.29 \\
\hline${ }^{@}$ Total & 99.33 & 99.58 & 100.01 & 99.29 & 99.28 & 99.53 \\
\hline $\mathrm{Co}$ & 13 & 19 & 23 & 14 & 15 & 9 \\
\hline $\mathrm{Ni}$ & 110 & 50 & 190 & 114 & 113 & 102 \\
\hline $\mathrm{Ga}$ & 33 & 19 & 57 & 35 & 27 & 35 \\
\hline $\mathrm{Rb}$ & 62 & 140 & 107 & 57 & 69 & 62 \\
\hline $\mathrm{Sr}$ & 340 & 170 & 588 & 290 & 513 & 225 \\
\hline $\mathrm{Zr}$ & 61 & 160 & 106 & 60 & 52 & 72 \\
\hline $\mathrm{Ba}$ & 778 & 580 & 1346 & 778 & 779 & 790 \\
\hline
\end{tabular}

- *Normalized data (C) of present study (A) in relation to average shale (B), that is excess carbonate free data.

- $\mathrm{n}=$ number of samples.

- Average shale (B): from Li (2000).

- $\quad * * \mathrm{Fe}_{2} \mathrm{O}_{3} \mathrm{t}=\mathrm{Fe}_{2} \mathrm{O}_{3}+\mathrm{FeO} \times(1.111) ; \mathrm{Fe}_{2} \mathrm{O}_{3 \mathrm{t}}=$ Total $\mathrm{Fe}_{2} \mathrm{O}_{3}$

- $\quad * * *\left(\mathrm{H}_{2} \mathrm{O}^{+}\right)$and $\left(\mathrm{CO}_{2}\right)$ are from Turekian and Wedepohl (1961).

- @ Total : excluding $\mathrm{Fe}_{2} \mathrm{O}_{3}$ and $\mathrm{FeO}$ 
Table 2: Average of ideal chemical compositions of clay minerals and albite.

\begin{tabular}{|c|c|c|c|c|c|}
\hline & Illite & Chlorite & Kaolinite & Montmorillonite & Albite \\
\hline $\mathrm{SiO}_{2}$ & 51.26 & 29.87 & 45.65 & 52.38 & 68.74 \\
\hline $\mathrm{Al}_{2} \mathrm{O}_{3}$ & 21.12 & 14.48 & 37.37 & 18.31 & 19.44 \\
\hline $\mathrm{TiO}_{2}$ & 0.29 & -- & 0.80 & 0.12 & -- \\
\hline $\mathrm{Fe}_{2} \mathrm{O}_{3}$ & 9.04 & 7.69 & 0.72 & 2.82 & -- \\
\hline $\mathrm{MgO}$ & 3.19 & 33.06 & 0.47 & 3.93 & -- \\
\hline $\mathrm{CaO}$ & 0.48 & -- & 0.48 & 1.87 & -- \\
\hline $\mathrm{Na}_{2} \mathrm{O}$ & 0.43 & -- & 0.20 & -- & 11.82 \\
\hline $\mathrm{K}_{2} \mathrm{O}$ & 6.5 & -- & 0.63 & -- & -- \\
\hline $\mathrm{H}_{2} \mathrm{O}^{+}$ & 7.53 & 14.60 & 13.26 & 19.78 & -- \\
\hline Total & $\mathbf{9 9 . 8 4}$ & $\mathbf{9 9 . 7 0}$ & $\mathbf{9 9 . 5 8}$ & $\mathbf{9 9 . 2 1}$ & $\mathbf{1 0 0 . 0}$ \\
\hline
\end{tabular}

Illite: average of (4) analyses $(1,2,5,6,7,8,9,10)$ Grim (1968, p.580).

Chlorite: Analysis (3) Grim (1968, p.581).

Kaolinite: average of (5) analyses (1-5) Grim (1968, p.576).

Montmorillonite: average of (7) analyses (1-7) Grim (1968, p.578).

Albite: from the ideal formula $\mathrm{NaAlSi}_{3} \mathrm{O}_{8}$.

Table 3: Mineral compositions of marl of the present study $(n=32)$.

\begin{tabular}{|c|c|c|c|c|}
\hline Mineral & Percent & & & \\
\hline Illite & 28 & \multirow{4}{*}{$\begin{array}{c}\text { Clay } \\
\text { minerals }=39 \%\end{array}$} & \multirow{7}{*}{$\begin{array}{c}\text { Detrital } \\
\text { fraction }=58 \%\end{array}$} & \\
\hline Chlorite & 8 & & & \\
\hline Kaolinite & 2 & & & \\
\hline Montmorillonite & 1 & & & \\
\hline Quartz & 15 & & & \\
\hline Albite & 1 & & & \\
\hline * Others & 3 & & & \\
\hline Calcite & 38 & & & Chemical \\
\hline Dolomite & 4 & & & fraction $=42 \%$ \\
\hline Total & 100 & & & \\
\hline
\end{tabular}

* Haematite and Ti-minerals; $\quad \mathrm{n}=$ no. of samples. 


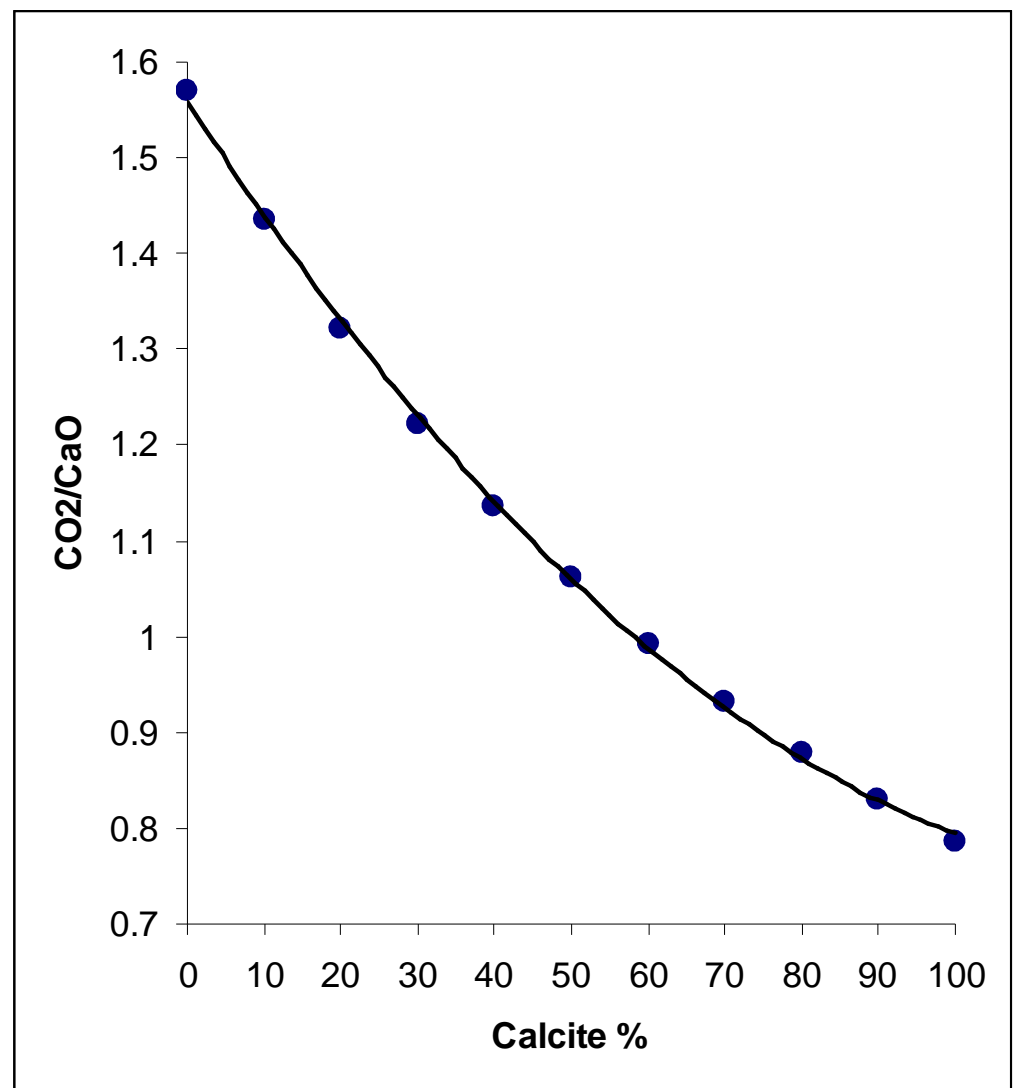

Fig. 2: Calcite percent versus $\left(\mathrm{CO}_{2} / \mathrm{CaO}\right)$ ratio of a hypothetical mixture of calcite and dolomite. Data from Table (4).

Table 4: Mixtures of calcite and dolomite and the ratio of $\mathrm{CO}_{2} / \mathrm{CaO}$.

\begin{tabular}{|c|c|c|c|c|c|}
\hline & Calcite \% & Dolomite \% & $\mathbf{C a O}$ & $\mathbf{C O}_{2}$ & $\mathbf{C O}_{2} / \mathbf{C a O}$ \\
\hline 1 & 0 & 100 & 30.41 & 47.73 & 1.570 \\
\hline 2 & 10 & 90 & 32.972 & 47.354 & 1.436 \\
\hline 3 & 20 & 80 & 35.534 & 46.972 & 1.322 \\
\hline 4 & 30 & 70 & 38.096 & 46.602 & 1.223 \\
\hline 5 & 40 & 60 & 40.658 & 46.226 & 1.137 \\
\hline 6 & 50 & 50 & 43.22 & 45.85 & 1.061 \\
\hline 7 & 60 & 40 & 45.782 & 45.474 & 0.993 \\
\hline 8 & 70 & 30 & 48.344 & 45.098 & 0.933 \\
\hline 9 & 80 & 20 & 50.906 & 44.722 & 0.879 \\
\hline 10 & 90 & 10 & 53.468 & 44.346 & 0.829 \\
\hline 11 & 100 & 0 & 56.03 & 43.97 & 0.785 \\
\hline
\end{tabular}

\section{GEOCHEMISTRY}

Geochemical study is carried out through the discussion of the distribution of major oxides, minor and trace elements and the comparison with average shale of $(\mathrm{Li}, 2000)$ (Table 1). Correlation coefficient matrix (Table 5) is also used for the interpretation of 
inter-element relationships. The averages of red and green marl samples (Table 1 DandF) are sometimes referred to, especially when discussing the green colour of marl of present study. The excess carbonate-free average of marl (Table 1C) is also shown to see how much close the marl of present study to the average shale of $\mathrm{Li}$ (2000). The table was calculated by fixing the carbonate oxides $\left(\mathrm{CaO}, \mathrm{MgO}\right.$ and $\left.\mathrm{CO}_{2}\right)$ with values as in the average shale, then using the correction factor of (1.7296). This is done to eliminate the dilution factor of the carbonates.

\section{Silica $\left(\mathrm{SiO}_{2}\right)$ :}

Silica in argillaceous rocks, including marl, usually occurs in two main phases; in the clay minerals, in the $\left(\mathrm{SiO}_{4}\right)$ tetrahedral sheet and as free silica in the mineral quartz, or as microcrystalline silica in the minerals like chert $\left(\mathrm{SiO}_{2}\right)$, jasper $\left(\mathrm{SiO}_{2}\right)$ and opal $\left(\mathrm{SiO}_{2} \cdot \mathrm{n} \mathrm{H}_{2} \mathrm{O}\right)$.

The average silica content of marl of the present study (33.77\%) is much lower than that of average shale (58.83) of Li (2000), Table 1 (A and B). The reason is the relatively high carbonate contents $(>40 \%)$ which act as a dilution factor for the silica and other oxides in the marl (Dhannoun et al., 1988). However, when the dilution factor is eliminated by assigning the values for carbonates $\left(\mathrm{MgO}, \mathrm{CaO}\right.$ and $\left.\mathrm{CO}_{2}\right)$ as for the average shale and the average is recalculated on "excess carbonate-free basis", the $\mathrm{SiO}_{2}$ content of the marl surprisingly becomes very close to (58.41\%) to that of average shale, Table 1 (B and C).

Correlation coefficient matrix (Table 5) shows that $\mathrm{SiO}_{2}$ has positive correlation with the oxides $\left(\mathrm{Al}_{2} \mathrm{O}_{3}, \mathrm{TiO}_{2}, \mathrm{Na}_{2} \mathrm{O}\right.$ and $\left.\mathrm{K}_{2} \mathrm{O}\right)$. These oxides with considerable part of $\left(\mathrm{SiO}_{2}\right)$ constitute the clay minerals and together with quartz, and iron oxide, they make up the bulk of detrital fraction, which was formed as mineral phases in the weathering zone and transported to the basin of deposition.

On the other hand, $\left(\mathrm{SiO}_{2}\right)$ and the other detrital oxides have strong negative correlations with $\left(\mathrm{CaO}\right.$ and $\left.\mathrm{CO}_{2}\right)$ which both make up the bulk of carbonate minerals, calcite and dolomite. Normative calculations show that $(56.6 \%)$ of total $\left(\mathrm{SiO}_{2}\right)$ is within the clay minerals and albite and (43.4\%) is in the free silica, mainly quartz.

\section{Alumina $\left(\mathrm{Al}_{2} \mathrm{O}_{3}\right)$ :}

This oxide or its cation $\left(\mathrm{Al}^{3+}\right)$ forms the basic unit of structure of the clay minerals, being in the tetrahedral sheet (in four coordination with oxygen) and in the octahedral sheet (in six coordination with oxygen). This unusual behaviour of $\left(\mathrm{Al}^{3+}\right)$ is caused by the radius ratio $\left(\mathrm{Al}^{3+} / \mathrm{O}^{2-}\right)$ of $(0.36)$ which makes the aluminium cation on the border between octahedral and tetrahedral coordination (Mason and Moore, 1982).

The average $\left(\mathrm{Al}_{2} \mathrm{O}_{3}\right)$ of marl of the present study $(8.30 \%)$ is much lower than that of average shale (16.63\%) of $\mathrm{Li}(2000)$, Table 1 (A and B). However, when dilution factor of carbonates is eliminated, the average becomes (14.36) much closer to that of shale, Table 1 ( $\mathrm{A}, \mathrm{B}$ and $\mathrm{C})$. Another reason for the low $\left(\mathrm{Al}_{2} \mathrm{O}_{3}\right)$ content is the type of clay minerals. The two most common clay minerals in marl of present study, illite $(28.15 \%)$ and chlorite $(8.33 \%)$ (Table 3), both have rather low $\left(\mathrm{Al}_{2} \mathrm{O}_{3} / \mathrm{SiO}_{2}\right)$ ratio of $(0.41)$ and $(0.48)$ respectively compared with $(0.82)$ for kaolinite (Table 2 ). 


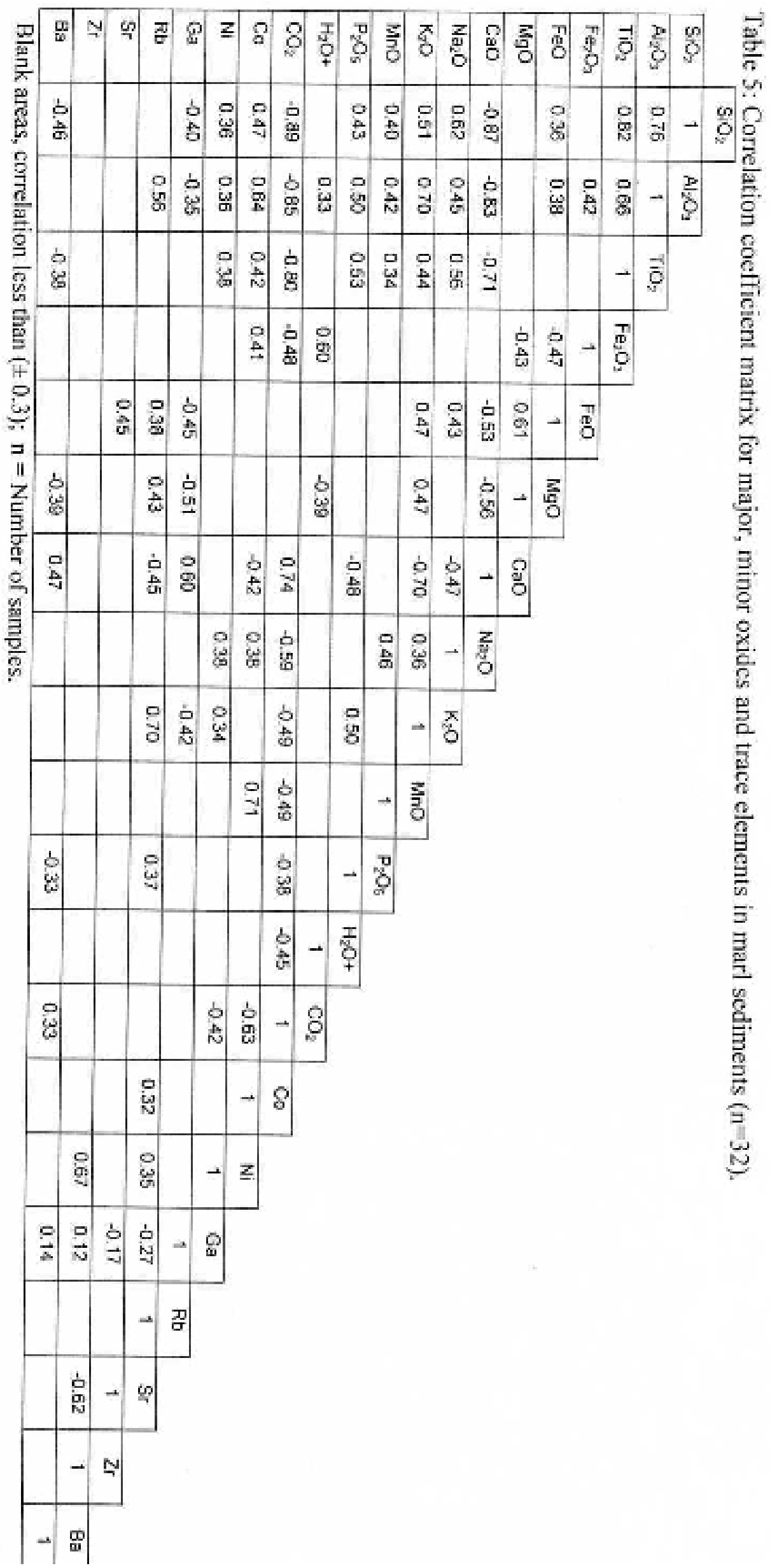


Correlation coefficient matrix (Table 5) shows that $\left(\mathrm{Al}_{2} \mathrm{O}_{3}\right)$ has medium to good positive correlation with oxides of detrital fraction $\left(\mathrm{SiO}_{2}, 0.76 ; \mathrm{TiO}_{2}, 0.66 ; \mathrm{Fe}_{2} \mathrm{O}_{3}, 0.42\right.$ and $\left.\mathrm{K}_{2} \mathrm{O}, 0.75\right)$. These oxides represent the clay minerals, quartz, heavy minerals and iron oxides. On the other hand, it has strong negative correlation with oxides of chemical fraction $\left(\mathrm{CaO},-0.83\right.$ and $\left.\mathrm{CO}_{2},-0.85\right)$.

\section{Titanium dioxide $\left(\mathrm{TiO}_{2}\right)$ :}

Titanium is one of the most immobile elements and its occurrence in sedimentary rocks is almost wholly restricted to the detrital fractions that is the clay minerals, iron oxides and the heavy minerals. In the clay minerals, $\left(\mathrm{Ti}^{4+}\right)$ may replace $\left(\mathrm{Al}^{3+}\right)$ or $\left(\mathrm{Mg}^{2+}\right)$ in octahedral sites, especially in kaolinite and chlorite (Grim, 1968; Aljubouri, 1972; Phillips and Griffen, 1981). Iron oxides, especially haematite $\left(\mathrm{Fe}_{2} \mathrm{O}_{3}\right)$ nearly always contain some amounts of $\left(\mathrm{Ti}^{4+}\right)$. Most sedimentary rocks contain detrital grains of rutile as a heavy mineral (Sp.Gr. 4.2, Hurlbut and Klein, 1977).

The average $\left(\mathrm{TiO}_{2}\right)$ of marl of the present study $(0.44 \%)$ is less than the average shale $(0.77 \%)$ of $\mathrm{Li}(2000)$ (Table $1 \mathrm{~A})$. However, when dilution factor of the carbonates is eliminated, the average becomes $(0.76 \%)$ and almost identical to that of average shale (Table $1 \mathrm{~B}$ and $\mathrm{C}$ ).

In the correlation matrix of table (2), $\mathrm{TiO}_{2}$ is positively correlated with the oxides of the detrital fraction $\left(\mathrm{SiO}_{2}, 0.82 ; \mathrm{Al}_{2} \mathrm{O}_{3}, 0.66 ; \mathrm{Na}_{2} \mathrm{O}, 0.56 ; \mathrm{K}_{2} \mathrm{O}, 0.44\right)$ indicating its association with the clay minerals.

Normative calculations (Table 3) show that $(77 \%)$ of $\left(\mathrm{TiO}_{2}\right)$ is in the free form possibly in the heavy mineral rutile and only $(23 \%)$ is in the clay minerals.

\section{Iron Oxides $\left(\mathrm{Fe}_{2} \mathrm{O}_{3}\right.$ and $\left.\mathrm{FeO}\right)$ :}

Iron in the marl of the present study was calculated as $\mathrm{Fe}_{2} \mathrm{O}_{3}$ and $\mathrm{FeO}$, since both valency states $\left(\mathrm{Fe}^{3+}\right.$ and $\left.\mathrm{Fe}^{2+}\right)$ are present and play an important part in the colour of marl sediments.

A considerable part of $\mathrm{Fe}^{3+}$ in the brown marl is present as free iron oxide in the mineral haematite $\left(\mathrm{Fe}_{2} \mathrm{O}_{3}\right)$ which is responsible for the brown or red colour of the sediments. In the green marl, haematite is absent and the majority of $\mathrm{Fe}^{3+}$ and $\mathrm{Fe}^{2+}$ are present within clay minerals.

In all the clay minerals of the present study (illite, chlorite, kaolinite and montmorillonite), $\mathrm{Fe}^{3+}$ must appear in the octahedral sheet, either replacing $\mathrm{Al}^{3+}$ or replacing $\mathrm{Mg}^{2+}$ to balance charge deficiency in tetrahedral sheet, caused by the substitution of $\mathrm{Al}^{3+}$ for $\mathrm{Si}^{4+}$ as in chlorite. In rare cases, $\mathrm{Fe}^{3+}$ is known to replace some $\mathrm{Si}^{4+}$ in the tetrahedral sheet of chlorite (Grim, 1968).

The ferrous iron $\mathrm{Fe}^{2+}$ seems to be restricted to chlorite where it replaces $\mathrm{Mg}^{2+}$ in the octahedral sheet in any proportion. However, haematite may contain minor amounts of $\mathrm{Fe}^{2+}$ (Phillips and Griffen, 1981).

The average $\mathrm{Fe}_{2} \mathrm{O}_{3}$ total of marl sediments of the present study $(5.59 \%)$ is lower than that of average shale (6.71\%) of Li (2000) (Table 1AandB). However, when dilution factor of carbonates is eliminated, the average becomes $(9.67 \%)$ higher than that of average shale (Table 1C) indicating an enrichment of marl sediments in iron oxides.

Correlation coefficient matrix (Table 5) shows that $\mathrm{Fe}_{2} \mathrm{O}_{3}$ has rather weak positive correlation with oxides of the detrital fraction $\left(\mathrm{SiO}_{2}, \mathrm{Al}_{2} \mathrm{O}_{3}\right.$ and $\left.\mathrm{TiO}_{2}\right)$. This is possibly 
due to the presence of (10) samples of green marl out of (32) samples, where $\mathrm{Fe}_{2} \mathrm{O}_{3}$ decreases in the reducing environments of the green marl, while the other oxides $\left(\mathrm{SiO}_{2}\right.$, $\mathrm{Al}_{2} \mathrm{O}_{3}$ and $\mathrm{TiO}_{2}$ ) increase in these environments (Table $1 \mathrm{D}$ and $\mathrm{E}$ ), thus weakening the rather strong positive correlation between $\mathrm{Fe}_{2} \mathrm{O}_{3}$ and these oxides.

Normative calculations (Table 3) show that (44\%) of $\mathrm{Fe}_{2} \mathrm{O}_{3}$ total is in the form of free iron oxide (haematite). The remaining $(56 \%)$ is within the clay minerals lattices, mainly in the octahedral sheet. These results are very close to that of Dhannoun and Al-Dabbagh (1990) (42\%) and Aljubouri et al. (1994) (42.56\%) for the distribution of free iron oxide in the Gercus (Eocene) red clastics.

\section{Magnesium Oxide (MgO), Calcium Oxide ( $\mathrm{CaO})$ and Carbon Dioxide $\left(\mathrm{CO}_{2}\right)$ :}

These three oxides constitute the bulk of the chemical fraction calcite and dolomite, which both, in contrast to the minerals of the detrital fraction, precipitated in the basin of deposition. However, a considerable part of $\mathrm{MgO}$ is within the detrital fraction, the clay minerals, mainly in the mineral chlorite. This is indicated by the positive correlation (although weak) between $\mathrm{MgO}$ and the oxides of the detrital fraction $\left(\mathrm{SiO}_{2}, \mathrm{Al}_{2} \mathrm{O}_{3}\right.$ and $\mathrm{TiO}_{2}$ ).

The negative correlation between $\mathrm{MgO}$ and $\mathrm{CaO}$ is partly because most $\mathrm{MgO}$ is within the detrital fraction and partly due to the fact that dolomitization (introduction of $\mathrm{MgO}$ ) reduces the original amount of $\mathrm{CaO}$. From table (3) it could be calculated that for each $(1 \%)$ dolomitization, $(0.3041 \% \mathrm{CaO})$ goes into dolomite and $(0.2562 \% \mathrm{CaO})$ is lost, i.e. goes into solution.

The average $(\mathrm{MgO})$ of marl of the present study $(5.37 \%)$ is higher than that of average shale $(2.49 \%)$ by a factor of (2), while the average $\mathrm{CaO}(22.76 \%)$ is higher by a factor of (10). The relatively high $(\mathrm{MgO}$ and $\mathrm{CaO})$ causes the dilution of the oxides of the detrital fraction (Aljubouri, 1972; Dhannoun et al., 1988; Aljubouri et al., 1994).

Correlation coefficient matrix shows that there is a strong negative correlation between $\left(\mathrm{CaO}\right.$ and $\left.\mathrm{CO}_{2}\right)$ and the oxides of the detrital fraction $\left(>-0.85\right.$ with $\mathrm{SiO}_{2}$ and $\mathrm{Al}_{2} \mathrm{O}_{3}$ and $>-0.7$ with $\mathrm{TiO}_{2}$ ), since the precipitation of carbonates is at the expense of the detrital fraction and leads to the observed negative correlation.

\section{Sodium Oxide $\left(\mathrm{Na}_{2} \mathrm{O}\right)$ and Potassium Oxide $\left(\mathrm{K}_{2} \mathrm{O}\right)$ :}

Sodium and potassium in argillaceous rocks usually occur in three forms: within chemical fraction, in the mineral halite $(\mathrm{NaCl})$ and sylvite $(\mathrm{KCl})$; in the detrital potassic and plagioclase feldspars and in the clay minerals. Most of the potassium is fixed in the mineral illite as an inter-layer cation. In the present study, the $\left(\mathrm{K}_{2} \mathrm{O}\right)$ analysis $(1.33 \%)$ (Table 1) is insufficient for the illite content $(28.15 \%$ in Table 3$)$ which requires $(1.83 \%$ $\left.\mathrm{K}_{2} \mathrm{O}\right)$. This is possibly due to the substitution of $\left(\mathrm{K}^{+}\right)$by molecular water or hydronium ion $\left(\mathrm{H}_{3} \mathrm{O}^{+}\right)$and the excess potassium goes into solution due to its very high mobility (Grim, 1968; Brindley and Brown, 1980; Aswad and Tobia, 2008).

Plagioclase feldspars, especially near albite $\left(\mathrm{NaAlSi}_{3} \mathrm{O}_{8}\right)$ always contain minor amount of potassium (Hurlbut and Klein, 1977). In the marl of the present study, plagioclase feldspar was identified by (XRD) and by thin section as oligoclase (Al-Kawaz, 1980; Aljubouri and Al-Kawaz, 2006) and hence some potassium could be within this oligoclase. 
Smectite (montmorillonite) always contains sodium (and calcium) as an inter-layer cation for charge balance (Phillips and Griffen, 1981, p.258), In the present study, montmorillonite was identified by (XRD) (Al-Kawaz, 1980; Aljubouri and Al-Kawaz, $2006)$ and the normative calculations gave (1.00\%) montmorillonite (Table 3$)$. As well as being within the structure of clay minerals, both $\mathrm{Na}$ and $\mathrm{K}$ are adsorbed on clay layers with broken bonds (Phillips and Griffen, 1981).

The normalized average $\mathrm{Na}_{2} \mathrm{O}$ and $\mathrm{K}_{2} \mathrm{O}$ of marl of the present study are $(0.42)$ and $(2.30 \%)$, respectively and both are lower than the average shale $(0.80 \%$ and $3.21 \%$ respectively, of $\mathrm{Li}(2000)$, Table 1 (A and $\mathrm{B})$. The reason is that there is no major mineral containing sodium, while potassium in illite was possibly subjected to substitution by $\left(\mathrm{H}_{2} \mathrm{O}\right)$ as stated earlier.

Correlation coefficient matrix (Table 5) clearly shows the positive correlation between $\left(\mathrm{Na}_{2} \mathrm{O}\right.$ and $\left.\mathrm{K}_{2} \mathrm{O}\right)$ and the oxides of the detrital fraction $\left(\mathrm{SiO}_{2}, \mathrm{Al}_{2} \mathrm{O}_{3}, \mathrm{TiO}_{2}\right.$ and $\mathrm{Fe}_{2} \mathrm{O}_{3}$ ) indicating their association with the clay minerals in this fraction. On the other hand, there is a negative correlation between these two oxides and $\left(\mathrm{CaO}\right.$ and $\left.\mathrm{CO}_{2}\right)$ of the chemical fraction indicating that there are no mineral phases of $\mathrm{Na}_{2} \mathrm{O}$ and $\mathrm{K}_{2} \mathrm{O}$ in this fraction.

\section{Manganese Oxide (MnO):}

The normalized average $(\mathrm{MnO})$ of marl of the present study $(0.17 \%)$ is higher than that of average shale $(0.11 \%)$ of $\mathrm{Li}(2000)$. The $(\mathrm{Fe} / \mathrm{Mn})$ ratio of $(50.8)$ is close to that of average shale (55) and very close to average ratio (50) of igneous rocks and the earth crust (Krauskopf, 1967). This means that nearly all the manganese released in the weathering zone from the weathering of igneous rocks is associated with iron as an oxide or hydroxide and/or both are within the clay minerals.

At the weathering zone, iron starts to precipitate as oxides and hydroxides at a $\mathrm{pH}$ from (6) to (8) in an oxidizing conditions, whereas very little ( $\mathrm{Mn})$ is precipitated at a $\mathrm{pH}$ of (8) due to its higher oxidation potential than iron. However, at a $\mathrm{pH}$ of (8.5) and higher iron continues to precipitate and $(\mathrm{Mn})$ starts to precipitate as the oxide $\left(\mathrm{MnO}_{2}\right)$ with oxides and hydroxides of iron (Krauskopf, 1967; Maynard, 2003; Stum and Morgan, 1996). However, an important part of iron is fixed within the octahedral sheet of the clay minerals.

Manganese in argillaceous rocks occurs either in the detrital fraction, within the clay minerals, heavy minerals and possibly as an independent phase in the mineral pyrolusite $\left(\mathrm{MnO}_{2}\right)$ or in the carbonate phase (Aljubouri, 1972; Tobia, 2005).

In chlorite, $\left(\mathrm{Mn}^{2+}\right)$ replaces some $\left(\mathrm{Mg}^{2+}\right)$ in the octahedral sheet, while haematite $\left(\mathrm{Fe}_{2} \mathrm{O}_{3}\right)$ contains minor amounts of $\left(\mathrm{Mn}^{2+}\right)$ (Phillips and Griffen, 1981).

In the correlation coefficient matrix of Table (5) manganese is positively correlated with the oxides of the detrital fraction $\left(\mathrm{SiO}_{2}, \mathrm{Al}_{2} \mathrm{O}_{3}, \mathrm{TiO}_{2}\right.$ and $\left.\mathrm{Fe}_{2} \mathrm{O}_{3}\right)$, whereas it has negative correlation with oxides of chemical fraction $\left(\mathrm{CaO}\right.$ and $\left.\mathrm{CO}_{2}\right)$. These relationships leave no doubt that $(\mathrm{MnO})$ of the present study is within the detrital fraction, i.e. within the clay minerals, iron oxides (haematite) and the heavy mineral rutile $\left(\mathrm{TiO}_{2}\right)$. 


\section{Phosphorus Pentoxide $\left(\mathrm{P}_{\mathbf{2}} \mathbf{O}_{\mathbf{5}}\right)$ :}

The normalized average $\left(\mathrm{P}_{2} \mathrm{O}_{5}\right)$ of marl of the present study $(0.31 \%)$ is almost twice that of average shale $(0.16 \%)$ of $\mathrm{Li}(2000)$ (Table $1 \mathrm{~A}$ and $\mathrm{B})$; however, it is the same as that for the average shale of Turakian and Wedepohl (1961).

The most common mode of occurrence of phosphorous in sedimentary rocks is in the mineral apatite, either as fluor-apatite $\left[\mathrm{Ca}_{5}\left(\mathrm{PO}_{4}\right)_{3} \mathrm{~F}\right]$ or carbonate apatite $\left[\mathrm{Ca}_{5}\left(\mathrm{PO}_{4}, \mathrm{CO}_{3}, \mathrm{OH}\right)_{3}(\mathrm{~F}, \mathrm{OH})\right]$ where it occurs as detrital grains or a primary deposit (Deer et al., 1967).

Phosphates are known to be concentrated in ironstone nodules (Schwertmann and Taylor, 1987). $\left(\mathrm{PO}_{4}{ }^{3-}\right)$ anions are known to become adsorbed or exchanged on clay minerals where they replace $\left(\mathrm{OH}^{-}\right)$ions exposed on the planar surfaces or around the edges of clay minerals (Degens, 1965). The ability of kaolinite to fix phosphate ions $\left(\mathrm{PO}_{4}{ }^{3-}\right)$ is of great importance in soil science (Deer et al., 1967).

In the present study, the negative correlation between $\left(\mathrm{P}_{2} \mathrm{O}_{5}\right)$ and $\left(\mathrm{CaO}\right.$ and $\left.\mathrm{CO}_{2}\right)$ (Table 5) rules out the probable occurrence of carbonate in the marl. On the other hand, the positive correlation between $\left(\mathrm{P}_{2} \mathrm{O}_{5}\right)$ and oxides of the detrital fraction $\left(\mathrm{SiO}_{2}, 0.43\right.$; $\mathrm{Al}_{2} \mathrm{O}_{3}, 0.42 ; \mathrm{TiO}_{2}, 0.34 ; \mathrm{Fe}_{2} \mathrm{O}_{3}, 0.28$ and $\mathrm{K}_{2} \mathrm{O}, 0.50$ ) leads to the conclusion that the bulk of $\left(\mathrm{P}_{2} \mathrm{O}_{5}\right)$ is within the clay minerals.

\section{Water of Crystallization $\left(\mathrm{H}_{2} \mathrm{O}^{+}\right)$:}

Water of crystallization $\left(\mathrm{H}_{2} \mathrm{O}^{+}\right)$is an essential constituent of all clay minerals which are also called "hydrous silicates" of aluminium and of magnesium.

In illite, hydronium ion $\left(\mathrm{H}_{3} \mathrm{O}^{+}\right)$or $\mathrm{H}_{2} \mathrm{O}^{+}$replaces some $\left(\mathrm{K}^{+}\right)$in the inter-layers of the structure leading to hydro-muscovite (Deer et al., 1967; Phillips and Griffen, 1981; Aswad and Tobia, 2008). In the present study, the calculated $\left(\mathrm{H}_{2} \mathrm{O}^{+} / \mathrm{K}_{2} \mathrm{O}\right)$ ratio in illite (Table 3) of (1.59) is higher than that in the ideal formula of (1.16) in illite (Table 2) indicating a possible replacement of $\left(\mathrm{K}_{2} \mathrm{O}\right)$ by $\left(\mathrm{H}_{2} \mathrm{O}\right)$ as stated earlier.

The normalized average $\left(\mathrm{H}_{2} \mathrm{O}^{+}\right)$of the marl of the present study of $(6.24 \%)$ is higher than that of Vinogradov (1962) of $(5.0 \%)$. There is no average $\left(\mathrm{H}_{2} \mathrm{O}^{+}\right)$in $\mathrm{Li}(2000)$ (Table 1B).

Correlation coefficient matrix (Table 5) shows that $\left(\mathrm{H}_{2} \mathrm{O}^{+}\right)$is positively correlated with oxides of the detrital fraction, while it is negatively correlated with oxides of the chemical fraction $\left(\mathrm{MgO}, \mathrm{CaO}\right.$ and $\left.\mathrm{CO}_{2}\right)$ suggesting that the bulk of $\left(\mathrm{H}_{2} \mathrm{O}^{+}\right)$is within the detrital fraction, the clay minerals.

\section{Cobalt (Co) and Nickel (Ni):}

These two transition elements are resistant to dissolution processes and remain in the solid products of breakdown processes for long periods and hence they remain in the detrital fraction of the source rocks during weathering. In sedimentary rocks, the two elements occur in two main phases; the clay minerals, where they replace $\mathrm{Fe}^{2+}, \mathrm{Fe}^{3+}$ and $\mathrm{Mg}^{2+}$ in the octahedral layer, since they have similar ionic radii $\left(\mathrm{Co}^{2+}, 0.72 \AA ; \mathrm{Fe}^{2+}, 0.74\right.$ $\AA ; \mathrm{Fe}^{3+}, 0.64 \AA$ ), and in iron oxides and hydroxides either adsorbed on the surfaces of iron oxide phaes or replacing $\mathrm{Fe}^{3+}$ or $\mathrm{Fe}^{2+}$ (Goldschmidt, 1958; Frolich, 1960; Aljubouri, 1972; Dhannoun et al., 1988). 
The normalized averages of $\mathrm{Co}$ and $\mathrm{Ni}$ in the marl of the present study are (13 ppm) and (190 ppm) respectively. Cobalt is slightly higher than that of average shale (19 ppm) and nickel is much higher, (3.8 times) as that of the average shale of (50 ppm) (Li, 2000).

In the correlation coefficient matrix of Table (2), the two elements are positively correlated with the oxides of the detrital fraction $\left(\mathrm{SiO}_{2}, \mathrm{Al}_{2} \mathrm{O}_{3}, \mathrm{TiO}_{2}, \mathrm{Fe}_{2} \mathrm{O}_{3}, \mathrm{Co}\right.$ only, $\mathrm{Na}_{2} \mathrm{O}$ and $\mathrm{K}_{2} \mathrm{O}$ ) indicating their similar geochemical behaviour and their possible associations with clay minerals and iron oxides. They are usually adsorbed on iron oxides surfaces which are considered to be as scavengers for these elements (Krauskopf. 1967; Kessler and Muller, 1988; Schwertman et al., 1989).

\section{Gallium (Ga) and Rubidium (Rb):}

The two elements are often found in the same mineral phases; in igneous and metamorphic rocks; they are usually occur within the $\mathrm{K}$-feldspars $\left(\mathrm{KAlSi}_{3} \mathrm{O}_{8}\right)$, and micas. Rubidium substitutes for potassium $\left(\mathrm{K}^{+}, 1.33 \AA\right.$ ) with similar ionic radius, while gallium substitutes for aluminium $\left(\mathrm{Al}^{3+}, 0.51 \AA\right)$. In sedimentary rocks, the most common mode of occurrence of these two elements is within clay minerals, especially in illite (KAl-silicate).

The normalized average $(\mathrm{Ga})$ content of marl of the present study $(57 \mathrm{ppm})$ is quite higher than that of average of shale $(19 \mathrm{ppm})$ of Li (2000). On the other hand, the normalized average $(\mathrm{Rb})$ content $(107 \mathrm{ppm})$ is lower than the average shale $(140 \mathrm{ppm})$, Table 1 (A and $\mathrm{B})$. While it is possible to explain the low $(\mathrm{Rb})$ content which is due to low $\mathrm{K}_{2} \mathrm{O}$ content $(2.30 \%)$, it is not easy at this stage to explain the high Ga content, since the average $\mathrm{Al}_{2} \mathrm{O}_{3}(8.30)$ is much lower (about half) than that of average shale $(16.62 \%)$ (Table $1 \mathrm{~A}$ and $\mathrm{B}$ ).

Correlation coefficient matrix (Table 2) shows that rubidium is positively correlated with the oxides of the detrital fraction $\left(\mathrm{Al}_{2} \mathrm{O}_{3}, \mathrm{FeO}, \mathrm{MgO}\right.$ and $\left.\mathrm{K}_{2} \mathrm{O}\right)$ having the highest correlation of (0.70) with potassium and leaving no doubt that $(\mathrm{Rb})$ is within the detrital fraction substituting for potassium in illite. On the other hand, gallium has negative correlation with all these oxides and a positive correlation with $\mathrm{CaO}(+0.60)$. This is rather unusual for gallium $\mathrm{Ga}^{3+}$ which has much smaller ionic radius $(0.62 \AA)$ than calcium $(0.99 \AA)$ and it has a higher charge too; so it is very unlikely to substitute for calcium.

Marl samples of the present study are divided into two populations or groups, red marl population (12 samples) and green marl population (10 samples). Correlation coefficient matrix for the red marl (Al-Kawaz, 1980) shows that (Ga) has strong negative correlation with oxides of the detrital fraction with the exception of $(\mathrm{FeO})$ where it has strong positive correlation (0.72) and therefore, it may be concluded that the bulk of gallium in the red marl is substitute for ferrous iron $\left(\mathrm{Fe}^{2+}\right)$ within ferrous minerals. Aljubouri (1972) in his study of marl of Triassic age (Keuper marl) at East Midland area, England, stated that gallium substitutes for $\mathrm{Fe}^{2+}$. In the present study, positive correlation between gallium and $\mathrm{CaO}(0.70)$ is perhaps indirect. Possible analytical error for gallium is perhaps responsible for this unusual behavior.

On the other hand, correlation coefficient matrix for the green marl (Al-Kawaz, 1980) shows that gallium has positive correlation with oxides of the detrital fraction $\left(\mathrm{Al}_{2} \mathrm{O}_{3}, \mathrm{TiO}_{2}\right.$ and $\left.\mathrm{Fe}_{2} \mathrm{O}_{3}\right)$ indicating its presence within the clay minerals substituting for $\left(\mathrm{Al}^{3+}\right)$ and within iron oxides substituting for $\left(\mathrm{Fe}^{3+}\right)$. In the reducing 
environments of the green marl, there was perhaps dissolution and reconstitution of some clay mineral phases leading to redistribution of gallium from the ferrous iron site (within clay minerals) into $\left(\mathrm{Al}^{3+}\right)$ and $\mathrm{Fe}^{3+}$ sites in the octahedral layers.

\section{Strontium (Sr) and Barium (Ba):}

The most common modes of occurrence of strontium and barium in sedimentary rocks are: (a) within carbonates and sulphates, substituting for calcium, especially strontium, since it has similar ionic radius $(1.12 \AA)$ to calcium $(0.99 \AA)$. Barium has relatively larger ionic radius (1.34 $\AA$ ) and hence smaller amounts of $\mathrm{Ba}^{2+}$ compared with strontium could substitute for calcium (Krauskopf, 1967; Deer et al., 1967); (b) within clay minerals, either adsorbed on clay mineral surfaces or substituting for inter-layer cations like potassium and calcium. Barium could easily substitutes for potassium (ionic radius $1.33 \AA$ ) in illite, having very similar ionic radius. Strontium with ionic radius between calcium and potassium can substitute for both (Carrol, 1958; Krauskopf, 1967); (c) as an independent phase in the sulphate (barite, celestite and baritocelestite); in the carbonates strontianites $\left(\mathrm{SrCO}_{3}\right)$ and witherite $\left(\mathrm{BaCO}_{3}\right)$.

In addition, smaller amounts of ( $\mathrm{Sr}$ and $\mathrm{Ba}$ ) are usually found within feldspars substituting for potassium in the K-feldspars and for calcium in the plagioclase feldspars, which always contain minor amounts of K-feldspars (Phillips and Griffen, 1981). The averages of $\mathrm{Sr}$ and $\mathrm{Ba}$ contents of marl of the present study (540 ppm and $776 \mathrm{ppm}$ ) respectively, higher than the average of $(170 \mathrm{ppm}$ for $\mathrm{Sr})$ and $(580 \mathrm{ppm}$ for $\mathrm{Ba})$ (Li, 2000), Table 1 (AandB). Correlation coefficient matrix of Table (5) shows that strontium has positive correlation with $\mathrm{FeO}(0.45)$ only, and an insignificant correlation with the oxides $\left(\mathrm{Al}_{2} \mathrm{O}_{3}, \mathrm{Na}_{2} \mathrm{O}\right.$ and $\left.\mathrm{K}_{2} \mathrm{O}\right)$ indicating its probable presence in the clay minerals or the detrital fraction.

Barium, on the other hand, has negative correlation with oxides of the detrital fraction $\left(\mathrm{SiO}_{2}, \mathrm{TiO}_{2}\right.$ and $\left.\mathrm{MgO}\right)$ and positive correlation with $\mathrm{CaO}(0.47)$ and $\mathrm{CO}_{2}(0.33)$ indicating its association with carbonate phase, in the mineral calcite or perhaps as an independent carbonate phase, witherite $\left(\mathrm{BaCO}_{3}\right)$. The calculated amount of witherite is $(0.11 \%)$. Strontium may be present in this phase, replacing $\left(\mathrm{Ba}^{2+}\right)$ as well as within the clay minerals, replacing potassium.

Both elements or part of them could be within the detrital plagioclase feldspar which was identified as oligoclase (Al-Kawaz, 1980; Aljubouri and Al-Kawaz, 2006, plate 3). In this case, they substitute for potassium in K-feldspr present as minor amounts as well as for calcium in plagioclase.

\section{Zirconium (Zr):}

Zirconium in sedimentary rocks is generally accepted to be represented by zircon $\left(\mathrm{ZrSiO}_{4}\right)$, which is the residual product of physical weathering of igneous rocks (Goldschmidt, 1958; Vlasov, 1964). Zircon is resistant to weathering and chemical alteration. It is usually transported to the area deposition as detrital grains together with the clay minerals. Zircon constitutes part of the heavy minerals having specific gravity of (4.68) and hardness (7.5) (Hurlbut and Klein, 1977).

The normalized average ( $\mathrm{Zr}$ ) content of marl of the present study (106 ppm) is less than that of average shale of (160 ppm) of Li (2000) (Table 1A and B). 
Correlation coefficient matrix (Table 5) shows that $(\mathrm{Zr})$ has no significant correlation with any of the major oxides, either in detrital or chemical fractions. This may indicate its presence mainly as an independent detrital grain and hence it is concentrated in very small amounts. It is not much affected by variations, increase or decrease, within the marl sediments.

\section{COLOUR OF MARL SEDIMENTS}

In the studied localities, two main colours of marl sediments were observed; these are red and green. Some samples are "drab" in colour (very pale brown to pale yellow) and their colour is considered as a shade of the red colour. The distribution of these colours within the collected samples is shown in Table (6).

The red colour is restricted to Shaikhan (5 samples) and Shaikh Ibrahim (7 samples). All Mishraq (8) samples are green and all Makhmur (4) samples are drab.

There is a vast amount of work on the red and green colours of argillaceous sediments and only few will be cited here. Nearly all workers agree that the cause of red colouration is the dispersion of the very fine grained pigment of haematite between and coating mineral grains of the sediments. The red colour and the presence of haematite are both an indication of oxidizing environment (Carroll, 1958; Aljubouri, 1972; Van Houten, 1973; Al-Rawi, 1983; Aljubouri et al., 1994). Green colour on the other hand, is caused by the presence of green clay minerals (green Fe-chlorite) with relatively high amounts of ferrous $\left(\mathrm{Fe}^{2+}\right)$ iron in their structure and it is an indication of a reducing environment (Grim, 1951; Dunham, 1955;Velde, 2003).

The ratio $\left(\mathrm{Fe}_{2} \mathrm{O}_{3} / \mathrm{FeO}\right)$ is an indicative of the oxidation state of the sediments. The percentage of $\left(\mathrm{Fe}_{2} \mathrm{O}_{3}\right)$ or $(\mathrm{FeO})$ alone is not important in influencing the intensity of the colour or the degree of oxidation, but the ratio of $\left(\mathrm{Fe}_{2} \mathrm{O}_{3} / \mathrm{FeO}\right)$ is the decisive factor. A ratio lower than (8) indicates reducing conditions, while higher ratios are indications of a more oxidizing environments (Van Houten, 1964, 1968; Friend, 1966; Aljubouri et al., 1994).

However, this is not always true, for example, the $\left(\mathrm{Fe}_{2} \mathrm{O}_{3} / \mathrm{FeO}\right)$ ratio in the Gercus (Middle Eocene) red marl (Al-Rawi, 1983) is only (7.36). Ferric oxide $\left(\mathrm{Fe}_{2} \mathrm{O}_{3}\right)$ in the red marl is always higher than the green marl, while ferrous oxide $(\mathrm{FeO})$ is the reverse being always higher in the green than in the red marl (Table 1DandE). Total iron $\left(\mathrm{Fe}_{2} \mathrm{O}_{3} \mathrm{t}\right)$ may be higher or lower in the red than in the green marl. Drab marl represents an intermediate composition in iron oxides. It has been observed that the intensity of red colour increases with the increase of ferric oxide $\left(\mathrm{Fe}^{3+}\right)$ or with increase of $\left(\mathrm{Fe}_{2} \mathrm{O}_{3 \mathrm{t}} / \mathrm{FeO}\right)$ ratio (Aljubouri, 1972; Aljubouri et al., 1994; Mohammed, 2007). There is no published work on the intensity of green colour. From the observations of colours and the concentrations of iron oxides a criteria for the colour of red and green argillaceous sediments in Iraq could be developed and is shown in Table (7).

The decrease in haematite pigment causes the sediments to be drab in colour (Aljubouri et al., 1994). In the present study, the drab marl has an average $\mathrm{Fe}_{2} \mathrm{O}_{3}\left(\mathrm{Fe}^{3+}\right)$ of $(3.86 \%)$ lower than that of red marl of $(5.13 \%)$ and may indicate leaching of some $\mathrm{Fe}_{2} \mathrm{O}_{3}$ pigment into the adjacent red marl sediments. Alternatively and since its $\mathrm{FeO}(0.77 \%)$ is higher than the red marl $(0.59 \%$; Table $1 \mathrm{D}$ and F), it may indicate a mild reducing environments where the reduction of haematite was incomplete. 
Table 6: Sample distributions in the studied localities and their colous.

\begin{tabular}{|c|c||c|c|}
\hline Sample No. & Colur & Sample No. & Colour \\
\hline 1 & R & 17 & R \\
\hline 2 & D & 18 & R \\
\hline 3 & G & 19 & R \\
\hline 4 & D & 20 & R \\
\hline 5 & R & 21 & G \\
\hline 6 & D & 22 & G \\
\hline 7 & R & 23 & G \\
\hline 8 & R & 24 & G \\
\hline 9 & R & 25 & G \\
\hline 10 & D & 26 & G \\
\hline 11 & D & 27 & G \\
\hline 12 & R & 28 & G \\
\hline 13 & D & 29 & D \\
\hline 14 & R & 30 & D \\
\hline 15 & R & 31 & D \\
\hline 16 & G & 32 & D \\
\hline
\end{tabular}

Samples (1-9), Shaikhan;

Samples (10-20), Shaikh Ibrahim

Samples (21-28), Mishraq

Samples (29-32), Makhmur

$\mathrm{R}=$ Red; $\mathrm{G}=$ Green; $\mathrm{D}=$ Drab

Table 7: Criteria for the colour of red and green argillaceous sediments in Iraq.

\begin{tabular}{|l|c|c|c|}
\hline \multirow{2}{*}{ Fe-oxides } & \multicolumn{3}{|c|}{ Colour } \\
\cline { 2 - 4 } & Red & Drab & Green \\
\hline $\mathrm{Fe}_{2} \mathrm{O}_{3}\left(\mathrm{Fe}^{3+}\right) \%$ & $>4.5$ & $3.5-4.5$ & $2-3.5$ \\
\hline $\mathrm{FeO} \%$ & $0.5-0.77$ & $0.77-0.9$ & $0.9-2.5$ \\
\hline $\mathrm{Fe}_{2} \mathrm{O}_{3 \mathrm{t}} \%$ & $>5$ & $<5$ & $>5$ \\
\hline $\mathrm{Fe}_{2} \mathrm{O}_{3 \mathrm{t}} / \mathrm{FeO}$ & $7-11$ & $6-7$ & $<6$ \\
\hline
\end{tabular}

In the present study, the reducing environments at Mishraq was most likely initiated by the presence of sulphate ions from gypsum deposits, organic matter from oil seepages and the sulphate reducing bacteria. The reduction of sulphates produces hydrogen sulphide $\left(\mathrm{H}_{2} \mathrm{~S}\right)$ gas which is oxidized by sulphates and producing native sulphur (Dhannoun and Saleh, 1976). $\mathrm{Fe}^{3+}$ in haematite in the red marl is reduced to the ferrous state $\left(\mathrm{Fe}^{2+}\right)$ which enters the structure of chlorite and forming green chlorites, like berthierene (ferrous, $7 \AA$ chlorite) and chamosite (ferrous aluminous $14 \AA$ chlorite) (Velde, 2003). The absence of red pigment due to the reduction of haematite and the formation of green chlorites result in the green colour of marl sediments at Mishraq. The presence of chlorite was proved by X-ray diffraction analysis (Aljubouri and Al-Kawaz, 2006) and by normative calculations (Table 3 ). The other two green samples represent very localized reducing environments due to local enrichment of solution with organic matter. 


\section{CONCLUSIONS}

Geochemical study of marl sediments concludes at the following points:

1. The marl sediments could be divided into two main fractions: detrital and chemical fractions with the oxides of each, in general, have negative correlation with the other. The mineral phases of the detrital fractions were brought to the basin of deposition from the weathering zone and suffered little alteration. The oxides of this fraction are $\mathrm{SiO}_{2}$ in the clay minerals and quartz; $\mathrm{Al}_{2} \mathrm{O}_{3}$ in the clay minerals and feldspars; $\mathrm{TiO}_{2}$ in Ti-minerals; $\mathrm{Fe}_{2} \mathrm{O}_{3}$ in the clay minerals and in iron oxides; $\mathrm{MgO}$ mostly in the clay minerals and partly in dolomite; $\mathrm{Na}_{2} \mathrm{O}$ and $\mathrm{K}_{2} \mathrm{O}$ in the clay minerals and feldspars; $\mathrm{MnO}, \mathrm{P}_{2} \mathrm{O}_{5}$ and $\mathrm{H}_{2} \mathrm{O}^{+}$are in the clay minerals. The mineral phases of the chemical fraction are the carbonates, calcite and dolomite which were precipitated in the basin of deposition and represented by the oxides $\left(\mathrm{CaO}\right.$, some $\mathrm{MgO}$ and $\left.\mathrm{CO}_{2}\right)$. The trace elements $(\mathrm{Co}, \mathrm{Ni}, \mathrm{Ga}, \mathrm{Rb}$ and some $\mathrm{Sr}$ and $\mathrm{Zr}$ ) are within the detrital fraction, mostly in the clay minerals and iron oxides. $\mathrm{Ba}$ and part of $\mathrm{Sr}$ are mostly within the carbonate phase.

2. Normative calculations show that detrital fraction constitutes around (58\%) of mineral phases and consists of illite $(28 \%)$, chlorite $(8 \%)$, kaolinite $(2 \%)$, montmorillonite $(1 \%)$, albite $(1 \%)$, quartz $(15 \%)$, haematite and Ti-minerals $(3 \%)$. The chemical fraction comprises about $(42 \%)$ of mineral phases, with calcite $(38 \%)$ and dolomite $(4 \%)$.

3. Colour study of marl sediments shows the presence of three colours: the red, is a primary colour and due to the red pigmentation of haematite from the weathering zone. The drab colour is possibly due to leaching of some haematite pigment from the sediments or due to mild reducing environments. The green colour is secondary in origin and due to the prevailing environments at Mishraq area, caused by the presence of organic matter from oil seepage. The $\left(\mathrm{Fe}^{3+}\right)$ in haematite was reduced to the ferrous $\left(\mathrm{Fe}^{2+}\right)$ state which enters the structure of the formed green chlorite minerals giving green colour to the sediments.

\section{REFERENCES}

Aljubouri, Z.A.J., 1972. Geochemistry, Origin and Diagenesis of Gypsum Deposits and Associated Sediments in the East Midland. Unpublised Ph.D. Thesis, University of Nottingham, England, U.K., , 411p.

Aljubouri, Z.A.J., Alkattan, M. and Alsayegh, A.Y., 1994. Geochemistry, Mineralogy and Colour of Gercus Formation at Zawita, Iraq. Africa Geoscience Review, Vol.1, No.4, pp.547-556.

Aljubouri, Z.A.J. and Al-Kawaz, H.M.A., 2006. Mineralogy and Petrography of marl Sediments Within the Fat'ha Formation in Selected Parts of Northern Iraq. Raf. Jour. Sci., Vol.17, No.1, pp.19-31.

Al-Kawaz, H.A.M., 1980. Geochemistry and Mineralogy of Marl Sediments Within the Fat'ha Formation in Selected Parts of Northern Iraq. Unpublised M.Sc. Thesis, University of Mosul, 112p.

Al-Rawi, Y., 1983. Origin of Red Colour in the Gercus Formation (Eocene), Northeastern Iraq. Sediment. Geol., 35, pp.175-192. 
Aswad, K.J. and Tobia, F.H., 2008. Indirect Evaluation of Chemical Composition in Illite/Smectite Interstratification and its Application in Palaeoenvironment of Deposition. Iraqi Jour. Earth Sci., Vol.8, No.1.

Brindley, G.W. and Brown, G., 1980. Crystal Structure of Clay Minerals and Their x-ray Identification. Mineralogical Society Monograph, No.5, London, 495p.

Carroll, D., 1958. Role of Clay Minerals in the Transportation of Iron. Geochim. Cosmochim. Acta, Vol.6, pp.268-281.

Deer, W.A.; Howie, R.A. and Zussman, J., 1967. An Introduction to Rock-Forming Minerals. Longman, London, 528p.

Degens, E.T., 1965. Geochemistry of Sediments: A Brief Survey. Printice-Hall, New Jersey, 342p.

Dhannoun, H.Y. and Al-Dabbagh, S.M.A., 1990. The Distribution of Fe, Mn, Ni, Cr and Co Between the Acid Soluble and Fe-oxides and Hydroxides and Matrix Fractions of the Gercus Red Beds of Northeastern Iraq. Chem. Geol., Vol.82, pp.57-68.

Dhannoun, H.Y. and Saleh, S.A., 1976. Mineralogy and Origin of Mishraq Sulphur Deposits, Northern Iraq. Raf. Jour. Sci., Vol.1, No.1, pp.3-18.

Dhannoun, H.Y., Al-Dabbagh, S.M.A. and Hasso, A.A., 1988. The Geochemistry of the Gercus Red Beds Formation of Northeastern Iraq. Chem. Geol., Vol.69, pp.87-93.

Dunham, K.C., 1955. Petrography of the Keuper Marl, pp.61-63. In: Stevensen, Rugelay and Uttoxeter: Mem. Geol. Surv. G.B., London, 140p.

Friend, P.F., 1966. Clay Fraction and Colour of Some Devonian Red Beds in the Catskill Mountains, U.S.A. J. Geol. Soc. London, Vol.122, pp.273-292.

Frolich, F., 1960. Contribution to the Geochemistry of Chromium. Geochim. Cosmochim. Acta, Vol.20, pp.215-240. In: Aljubouri, Z.A., 1972. Geochemistry, Origin and Diagenesis of Some Triassic Gypsum Deposits and Associated Sediments, England. Unpublised Ph. D. Thesis, 540p.

Goldschmidt, V.M., 1958. Geochemistry. Oxford University Press, London, 730p.

Grim, R.E., 1951. The Depositional Environment of Red and Green Shales. J. Sed. Petrol., Vol.21, pp.226-232.

Grim, R.E., 1968. Clay Mineralogy, $2^{\text {nd }}$ ed., Mc-Graw-Hill, New York, USA, 596p.

Hurlbut, C.S. and Klein, C., 1977. Manual of Mineralogy (after James Dana), Willey and Sons, New York, USA, 532p.

Krauskopf, K.B., 1967. Introduction to Geochemistry. Mc-Graw-Hill Book Company, New York, USA, 617p.

Leake, B.E., Hendry, G.L., Kemp, A., Plant, A,G., Harvey, P.K., Wilson, J.R., Coasts, J.S., Aucott, J.W., Lund, T. and Howarth, R.J., 1969. The Chemical Analysis of Rock Powders by Automatic X-ray Fluorescence. Chem. Geol., Vol.5, pp.7-86.

Li, Y.H., 2000. A compendium of Geochemistry: From Solar Nebula to Human Brain. In: Sediments, Diagenesis and Sedimentary rocks (ed. F.T. Mackenzie), Vol.7. Treatise on Geochemistry (ed. H.D. Holland and Turekian), Elsevier-Pergamon, Oxford, $425 p$.

Mason, B. and Moore, C.B., 1982. Principles of Geochemistry ( $4^{\text {th }}$ ed.). Wiley and Sons, New York, 344p. 
Maynard, J.B., 2003. Manganiferous Sediments, Rocks and Ores, pp.289-308. In: Sediments, Diagenesis and Sedimentary Rocks (ed. F.T. Mackanzie), Vol.7. Treatise on Geochemistry (ed. H.D. Holland and K.K. Turekian), ElsevierPergamon, Oxford, 425p.

Mohammed, F.A., 2007. Mineralogy and Geochemistry of the Red Beds Group Rocks, Northeastern Iraq. Unpublised Ph.D. Thesis, University of Mosul, 170p. (In Arabic).

Norrish, K. and Hutton, J.T., 1964. Preparation of Samples for Analysis by X-ray Spectroscopy. Div. Rep. Div. Soils, CSIRO, 3/64.

Phillips, W.M. and Griffen, D.T., 1981. Optical Mineralogy. Freeman, San Francisco, USA, 677p.

Schwertmann, U. and Taylor, R.M., 1987. Iron Oxides. In: Dixon, J.B. and Weed, S.B. (eds.), Minerals and Soil Environments. Soil Sci. Soc. Amer., 379p.

Schwertman, U., Garell, U. and Aticher, H., 1989. Chromium for Iron Substitution in Synthetic Goethite. Geochim. Cosmochim. Acta, Vol.53, pp.1293-1297.

Stum, W. and Morgan, J.J., 1996. Aquatic Chemistry. $3^{\text {rd }}$ ed., Wiley-Interscience, New York, 1022p. In: Sediments, Diagenesis and Sedimentary Rocks (ed. F.T. Mackanzie), Vol.7. Treatise on Geochemistry (ed. H.D. Holland and K.K. Turekian), Elsevier-Pergamon, Oxford, 425p.

Tobia, F.H., 2005. Mineralogy and Geochemistry of the Clastics of Jurassic System in Iraq, Western Desert. Unpublised. Ph.D. Thesis, University Of Mosul, 225p.

Turekian, K.K. and Wedepohl, K.H., 1961. Distribution of Elements in Some Major Rock Units of the Earth's Crust. Geol. Soc. Am. Bull/. Vol.72, pp.175-192.

Van Houten, F.B., 1964. Origin of Red Beds-Some Unsolved Problems. In: A.E.M. Nairn (Editor). Problems in Palaeoclimatology. Wiley-Interscience, New York, pp.647672.

Van Houten, F.B., 1968. Iron Oxide in Red Beds. Geol. Sci. Am. Bull., Vol.79, pp.399-416.

Van Houten, F.B., 1973. Origin of Red Beds, a review, 1961-1972. Earth Planet. Sci. Ann. Rev., Vol.1, pp.39-61.

Velde, B., 2003. Green Clay Minerals, pp.309-324. In: Sediments, Diagenesis and Sedimentary Rocks (ed. F.T. Mackanzie), Vol.7. Treatise on Geochemistry (ed. H.D. Holland and K.K. Turekian), Elsevier-Pergamon, Oxford.

Vinogradov, A.P., 1962. Average Contents of Elements in the Earth's Crust. Geochemistry, Vol.7, pp.641.

Vlasov, K.A, 1964. Geochemistry of Rare Metals. In: Aljulouri, 1972. Geochemistry, Origin and Diagenesis of Gypsum Deposits and Associated Sediments in the East Midland. Unpublised. Ph.D. Thesis, University of Nottingham, England, U.K., $411 \mathrm{p}$.

Wilson, A.D., 1955. A new Method for the Determination of Ferrous Iron in Rocks and Minerals. Bull. Geol. Surv. G. B., Vol.9, pp.56-58. 